\title{
Evolution and significance of soil magnetism of basalt-derived chronosequence soils in tropical southern China
}

\author{
Decheng $\mathrm{Li}^{\mathrm{i}^{\star}}$, Yanfang Yang ${ }^{1,2}$, Jinping Guo ${ }^{3}$, Bruce Velde ${ }^{4}$, Ganlin Zhang ${ }^{1}$, Feng $\mathrm{Hu}^{2}$, \\ Mingsong Zhao ${ }^{1}$

\footnotetext{
${ }^{1}$ State Key Laboratory of Soil and Sustainable Agriculture, Institute of Soil Science, Chinese Academy of Sciences, Nanjing, China;

*Corresponding Author: dcli@issas.ac.cn

${ }^{2}$ College of Resources and Environmental Science, Nanjing Agricultural University, Nanjing, China;

${ }^{3}$ Fujian Province Tobacco Company, Fuzhou, China;

${ }^{4}$ Laboratoire de Géologie, Ecole Normal Supérieure, Paris, France.
}

Received 25 August 2011; revised 10 October 2011; accepted 26 October 2011.

\begin{abstract}
Soil samples were collected from eight basaltderived chronosequence soils with the ages of $0.01,0.58,0.92,1.33,2.04,3.04,3.76$ and $6.12 \mathrm{Ma}$ respectively from Leizhou Peninsula and northern Hainan Island of tropical southern China. Magnetic parameters of magnetic susceptibility (MS), percentage of frequency-dependent magnetic susceptibility (FDS\%), anhysteretic remanent magnetization (ARM), saturation isothermal remanent magnetization (SIRM), soft and hard isothermal remanent magnetization $\left(\mathrm{IRM}_{s}\right.$ and $I M_{h}$ ) of the collected samples were measured to study the evolution and the significance of the magnetism with soil age. The results show that the magnetic parameters changed fast from Primosols to Ferrosols (0.01 - $0.92 \mathrm{Ma}$ ) but slowly at Ferralosols stage (1.33 Ma ), it suggests a stable phase occurred for soil magnetism at Ferralosols, the existence of this phase could be supported by the little changes in the contents of clay, $\mathrm{Fe}_{\mathrm{t}}$ and $\mathrm{Fe}_{\mathrm{d}}$. Obvious differences existed in the values of magnetic parameters between Ferralosols and other soil types (Primosols and Ferrosols), FDS\%: Ferralosols $>10 \%$, Primosols and Ferrosols $<10 \%$; ARM, Ferralosols $<7000 \times 10^{-8} \mathrm{SIm}^{3} \cdot \mathrm{kg}^{-1}$, Primosols and Ferrosols $>8000 \times 10^{-8} \mathrm{SIm}^{3} \cdot \mathrm{kg}^{-1}$, thus, it is possible to differentiate Ferralosols from other soil types in tropical region by using magnetic indices.
\end{abstract}

Keywords: Magnetic Parameters; Basalt-Derived
Chronosequence Soil; Iron Oxides; Tropical Southern China

\section{INTRODUCTION}

Soil chronosequences, given that the other soil-forming factors are similar, are often used to demonstrate the relative degree of soil development under varying duration of soil formation [1]. Studies have proved that different soil types may be formed from the same parent material in a region with the continuation of the weathering process, for examples, the systematical studies of soil development in Hawaii by Kennedy et al. [2], Chadwick et al. [3,4], Kurtz et al. [5] and Derry et al. [6] and in northern Hainan Island by Huang and Gong [7], Huang et al. [8,9] and Zhang et al. [10].

Magnetic measurement is a simple, quick and nondestructive technique for characterizing soils and sediments. Soil taxonomy has got remarkable achievements in the world, for examples, USDA-NRCS, 2010; IUSSISRIC-FAO, 2007; CRGCST, 2001. Although some researchers attempted to use magnetic susceptibility as a tool for soil classification to separate Oxisols, Ultisols and Entisols at a low taxonomic level [11-14], no quantitative diagnostic information of magnetism available in current soil taxonomy.

As Huang et al. [9] disclosed that basalt-derived soils in the tropical Leizhou Peninsula and Hainan Island of south China can develop gradually from Primosols into ferralic-horizon characterized Ferralosols [15], so here we collected chronosequence samples of basalt-derived soils in this region in 2007 to explore the possible significance of magnetic parameters in identifying soil types by studying the evolution of soil magnetism. 


\section{MATERIALS AND METHODS}

\subsection{Chronosequence Red Soil Samples}

The studied soils are from located in the tropical Leizhou Peninsula and northern Hainan island of southern China, where with a present tropical monsoon climate of a mean annual rainfall of $1400-1800 \mathrm{~mm}$ and a mean temperature of $23^{\circ} \mathrm{C}-24^{\circ} \mathrm{C}$. The change of climate during the Quaternary is negligible, which remains in a warm subtropical climate and no more than $2.5^{\circ} \mathrm{C}$ change of temperature [16]. The studied eight basalt-derived chronosequence soils (see Table 1) were located at uplands Soils, all sampled sites have udic soil moisture regimes and hyperthermic soil temperature regimes and under secondary shrub or forest vegetation. The ages of the parent basalt-rocks of the eight soil profiles were dated by using K-Ar methods [17-19], which could be taken roughly as the proxies of the time-spans of soil formation due to the general lack of well-dated soil real age [20].

$\mathrm{Fe}_{\mathrm{d}} / \mathrm{Fe}_{\mathrm{t}}$ usually can be used to validate the chronosequence reliability because it is a good indicator of the wearthering degree of soils [10,21-25], The increase of $\mathrm{Fe}_{\mathrm{d}} / \mathrm{Fe}_{\mathrm{t}}$ in $\mathrm{B}$ horizons with soil age proved the reliability of the studied chronosequence soils (Figure 1).

\subsection{Measurements of Soil Samples}

Soil magnetic parameters of all horizons of the sampled profiles were measured in the State Key Lab of Estuary and Coast of East China Normal University. Magnetic susceptibility (MS) was measured at low frequency $\left(0.47 \mathrm{kHz}, \mathrm{MS}_{\mathrm{lf}}\right)$ and high frequency $\left(4.7 \mathrm{kHz}, \mathrm{MS}_{\mathrm{hf}}\right)$ using a Bartington MS2 meter with dual frequency sensor. Frequency-dependent magnetic susceptibility (FDS\%) was calculated as: $\operatorname{FDS}(\%)=100 \times\left[\left(\mathrm{MS}_{\mathrm{lf}}-\mathrm{MS}_{\mathrm{hf}}\right) /\right.$ $\left.\mathrm{MS}_{\mathrm{lf}}\right]$. Anhysteretic remanent magnetization (ARM) was measured in the Molspin magnetometer after magnetization with a Molspin AF demagnetizer. The peak AF field used was $100 \mathrm{mT}$ and the DC bias was $0.04 \mathrm{mT}$. Isothermal remanent magnetization (IRM) was produced in progressively increasing magnetic fields up to $1000 \mathrm{mT}$ with a Molspin pulse magnetizer. IRM $\mathrm{IN00 \textrm {mT }}_{\mathrm{T}}$ was defined as the saturation isothermal remanent magnetization (SIRM). IRM ${ }_{20 \mathrm{mT}}$ was defined as soft IRM (IRM ${ }_{\mathrm{s}}$ ), and $\left(\mathrm{SIRM} \mathrm{IRM}_{300 \mathrm{mT}}\right)$ was defined as hard IRM $\left(\mathrm{IRM}_{\mathrm{h}}\right)$. $\mathrm{DC}_{-100 \mathrm{mT}}$ was defined as demagnetizing factor in $100 \mathrm{mT}$.

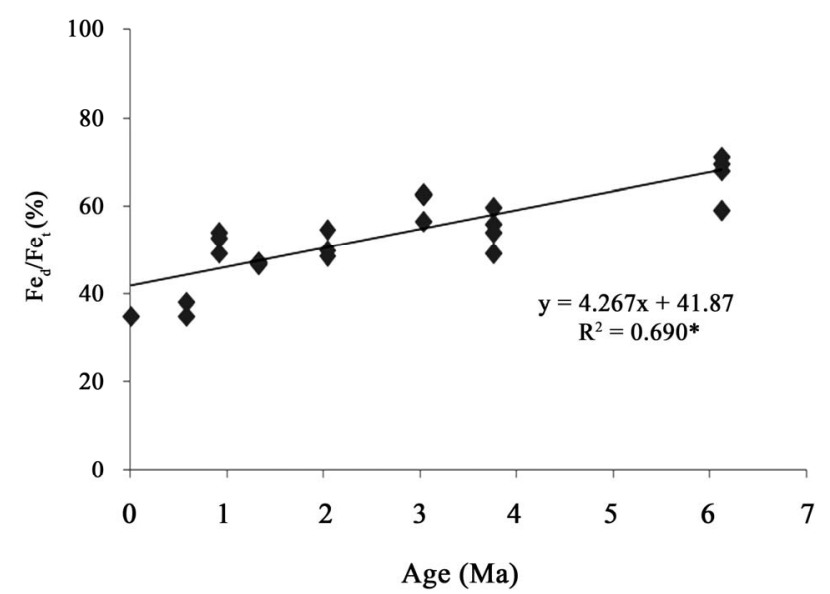

Figure 1. The temporal change of $\mathrm{Fe}_{\mathrm{d}} / \mathrm{Fe}_{\mathrm{t}}$ in $\mathrm{B}$ horizons of basalt-derived chronosequence soils.

Table 1. Basic information of basalt-derived chronosequence soils.

\begin{tabular}{|c|c|c|c|c|c|c|}
\hline Profile & Sampling site & Location & Soil age (Ma) & Soil type ${ }^{(\text {CRGCST, 2001) }}$ & Vegetation & Horizon $(\mathrm{cm})$ \\
\hline HN01 & $\begin{array}{l}\text { Shizilu town, } \\
\text { Northern Hainan }\end{array}$ & $\begin{array}{r}19^{\circ} 51.488^{\prime} \mathrm{N} \\
110^{\circ} 21.327^{\prime} \mathrm{E}\end{array}$ & 0.01 & Primosols & Pineapple, loquat, azedarach & $\begin{array}{l}\text { A } 0-16 \\
\text { B } 16-40 \\
\text { BC } 40-100 \\
\text { C > } 100\end{array}$ \\
\hline LZ01 & $\begin{array}{l}\text { Yinli town } \\
\text { Leizhou Peninsula }\end{array}$ & $\begin{array}{l}20^{\circ} 36.361^{\prime} \mathrm{N} \\
110^{\circ} 10.147^{\prime} \mathrm{E}\end{array}$ & 0.58 & Ferrosols & Sparse grass, shrub & $\begin{array}{l}\text { A } 0-20 \\
\text { B } 20-90 \\
\text { BC } 90-150 \\
\text { C }>150\end{array}$ \\
\hline LZ04 & $\begin{array}{l}\text { Chenbei town } \\
\text { Leizhou Peninsula }\end{array}$ & $\begin{array}{l}20^{\circ} 20.367^{\prime} \mathrm{N} \\
110^{\circ} 07.051^{\prime} \mathrm{E}\end{array}$ & 0.92 & Ferrosols & Eucalyptus, sparse grass & $\begin{array}{l}\text { A } 0-23 \\
\text { B } 23-105 \\
\text { BC }>105\end{array}$ \\
\hline HN03 & $\begin{array}{l}\text { Yongfa town } \\
\text { Northern Hainan }\end{array}$ & $\begin{array}{l}19^{\circ} 46.346^{\prime} \mathrm{N} \\
110^{\circ} 12.887^{\prime} \mathrm{E}\end{array}$ & 1.33 & Ferralosols & Azedarach, eucalyptus, & $\begin{array}{l}\text { A } 0-15 \\
\text { B } 15-118 \\
\text { BC }>118\end{array}$ \\
\hline LZ07 & $\begin{array}{l}\text { Nanshan town } \\
\text { Leizhou Peninsula }\end{array}$ & $\begin{array}{l}20^{\circ} 15.947^{\prime} \mathrm{N} \\
110^{\circ} 09.583^{\prime} \mathrm{E}\end{array}$ & 2.04 & Ferralosols & Eucalyptus, sparse grass & $\begin{array}{l}\text { A } 0-20 \\
\text { B } 20-120 \\
\text { BC }>120\end{array}$ \\
\hline LZ05 & $\begin{array}{l}\text { Haian town } \\
\text { Leizhou Peninsula }\end{array}$ & $\begin{array}{l}20^{\circ} 16.609^{\prime} \mathrm{N} \\
110^{\circ} 15.218^{\prime} \mathrm{E}\end{array}$ & 3.04 & Ferralosols & Eucalyptus, sparse grass & $\begin{array}{l}\text { A } 0-18 \\
\text { B } 18-120 \\
\text { BC }>120\end{array}$ \\
\hline HN04 & $\begin{array}{l}\text { Bailian town, } \\
\text { Northern Hainan }\end{array}$ & $\begin{array}{r}19^{\circ} 53.998^{\prime} \mathrm{N} \\
110^{\circ} 07.438^{\prime} \mathrm{E}\end{array}$ & 3.76 & Ferralosols & Eucalyptus, sparse grass & $\begin{array}{l}\text { A } 0-30 \\
\text { B } 30-120 \\
\text { BC }>120\end{array}$ \\
\hline LZ08 & $\begin{array}{l}\text { Hainan town } \\
\text { Leizhou Peninsula }\end{array}$ & $\begin{array}{l}20^{\circ} 17.662^{\prime} \mathrm{N} \\
110^{\circ} 11.441^{\prime} \mathrm{E}\end{array}$ & 6.12 & Ferralosols & Eucalyptus, sparse grass & $\begin{array}{l}\text { A } 0-20 \\
\text { B } 20-150 \\
\text { BC }>150\end{array}$ \\
\hline
\end{tabular}


Soil other properties were measured in the Soil and Environmental Analysis Center of the Institute of Soil Science, Chinese Academy of Sciences (ISSCAS) according to the standard methods outlined by the Chinese Society of Soil Science [26] (CSSS, 1984). The sand, silt and clay fractions were extracted by the pipette method. For the fine earths $(<2 \mathrm{~mm})$, the content of total iron $\left(\mathrm{Fe}_{\mathrm{t}}\right)$ was measured by ICP-AES method after hydrofluoric acid digestion and the content of free iron oxide $\left(\mathrm{Fe}_{\mathrm{d}}\right)$ was determined by the phenanthroline-colorimetry method after being extracted by the dithionitecitrate-bicarbonate solution (DCB) [27].

Particle size distribution (PSD) of clay fraction obtained by the pipette method was measured by laser diffraction (LD) method: soil samples were sieved by $2 \mathrm{~mm}$ mesh size after air-dried at room temperature, the organic matter was removed with $6 \% \mathrm{H}_{2} \mathrm{O}_{2}$, carbonate removed with $0.2 \mathrm{~mol} \cdot \mathrm{L}^{-1} \mathrm{HCl}, \mathrm{Ca}^{2+}$ and chlorides removed with $0.05 \mathrm{~mol} \cdot \mathrm{L}^{-1}$ dilute $\mathrm{HCl}$ and distilled $\mathrm{H}_{2} \mathrm{O}$. Then soil samples were put into $0.5 \mathrm{~mol} \cdot \mathrm{L}^{-1} \mathrm{NaOH}$ for a night after being shaken for several minutes and were dispersed with the supersonic method (160 w, 10 - 15 min), then PSD data were obtained by using Beckman
Coulter LS230 (He-Ne laser, $5 \mathrm{mw}$ power, $750 \mathrm{~nm}$ wavelength, 0.04 - $2000 \mu \mathrm{m}$ measuring range, about $0.1 \mathrm{~g}$ soil for each sample).

\section{RESULTS AND DISCUSSION}

\subsection{Temporal Changes of Magnetic Parameters}

The data of mesured magnetic parameters of $0.01 \mathrm{Ma}$ (Primosols), 0.58 Ma (Ferrosols), 1.33 Ma (young Ferrosols) and 6.12 Ma (old Ferralosols) were compared here to disclose the evolution of magntism with time (see Figure 2).

MS gives an approximate indicator of concentration of the ferrimagnetic minerals in the soil. From the irregular change of MS with soil age, we fails to find the decline tendency of magnetic susceptibility of basaltderived soils with pedogenic development or soil age as proposed by Lu et al. [25]. Most studies found that MS hardly can be used solely to indicate the pedogenic development becauese that fatcors which can affect MS are complicated [7].
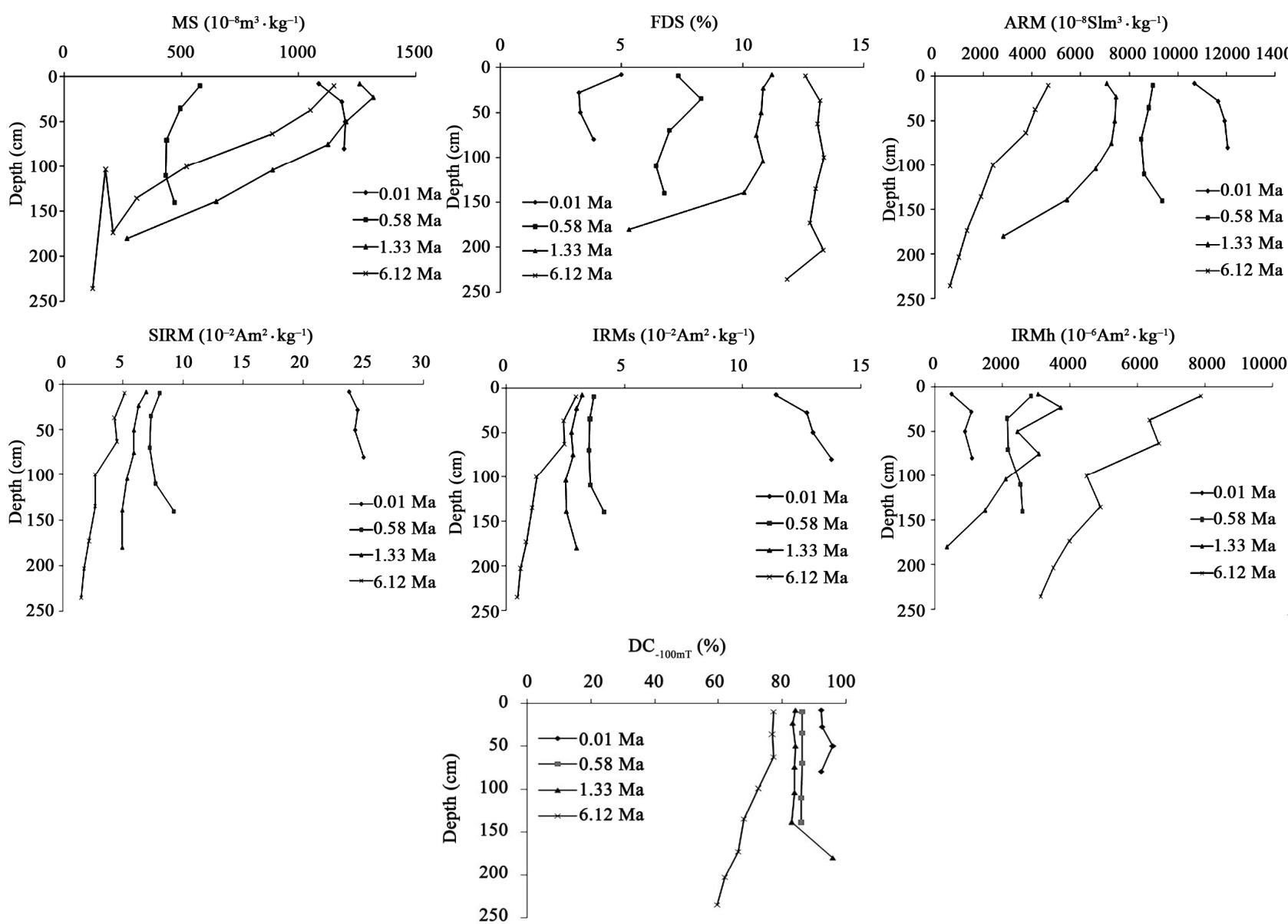

Figure 2. The temporal change of magentic parameters of basalt-derived chronosequence soils. 
From MS change from $\mathrm{C}$ to $\mathrm{BC}$ to $\mathrm{B}$ to $\mathrm{A}$ horizons it can be found that pedogenic process can enhance MS of basalt-derived soils as others have found it (for example, [7]). No significant correlation exitsed between MS and $\mathrm{Fe}_{\mathrm{t}}, \mathrm{Fe}_{\mathrm{d}}, \mathrm{Fe}_{\mathrm{o}}, \mathrm{Fe}_{\mathrm{d}} / \mathrm{Fe}_{\mathrm{t}}$ and $\mathrm{Fe}_{\mathrm{o}} / \mathrm{Fe}_{\mathrm{t}}$, which prove that MS is determined by the concentration of ferrimagentic minerals but not of iron iorn oxdies.

FDS indicates the presence of grains lying at the stable single domain (SSD)-superparamagnetic (SP) boundary, around $0.02 \mu \mathrm{m}$ for isodiametric grains [28,29], while ARM is generally more sensitively proportional to the concentration of SSD grains of ferrimagnetic minerals. According to Dearing's model [29], FDS of $0.01 \mathrm{Ma}$ profile is lower than $5 \%$, indicating little SP grains in the soil. FDS $\%$ of $0.58 \mathrm{Ma}$ profile ranges from $5 \%$ to $10 \%$, indicating significant amount of SP grains existed in the soil $[11,28]$. FDS of 1.33 Ma profile and 6.12 Ma profile both are higher than $10 \%$, suggesting more than $75 \%$ frequency-dependent ultra-fine SP grains appeared in the soils. The origin of the magnetic susceptibility in 0.01 $\mathrm{Ma}$ is believed to be inherited coarsed MD grains, while SP particles are assumed to be autogenic and suggest enhanced pedogenic development [30,31], thus, from the decrease of ARM and the increase of FDS with soil age, it may be concluded that SSD grains were weathered further into SP grains.

SIRM is a concentration-dependent magnetic parameter, while $\mathrm{IRM}_{\mathrm{s}}$ is more sensitively proportional to the concentration of coarsegrained (MD or PSD grains) ferrimagnetic minerals. The significantly positive liner correlation between SIRM and IRMs $\left(\mathrm{R}=0.991^{* *}, \mathrm{n}=\right.$ 24) proves that SIRM is dominantly contributed by IRM $_{s}$. SIRM and IRM $_{\mathrm{s}}$ decreased with soil age means MD and PSD grains decrased grudally. SIRM and $\mathrm{IRM}_{\mathrm{s}}$ of 0.01 Ma profile is higher than those of other three profiles, which means higher concentrations of coarsed-ferrimagnetic phases (e.g. magnetite and maghemite) in young profile due to the input of parent material. The rapid decrease of SIRM and IRM $_{\mathrm{s}}$ after $0.01 \mathrm{Ma}$ shows the quick reduce of ferrimagnetic phases with soil age in soils, howere, the reduce becomes slowly from $0.58 \mathrm{Ma}$ to 6.12 Ma, which means a slow decrease of MD or PSD grains of ferrimagnetic phases in the older soils.

$\mathrm{IRM}_{\mathrm{h}}$ can reflect the concentrations of antiferromagnetic minarals (e.g., hematite and goethite). $\mathrm{DC}_{-100 \mathrm{mT}}$ reflect the ratio of antiferromagnetic minerals to ferrimagentic minerals (e.g., magnetite and maghemite). The increase of $\mathrm{IRM}_{\mathrm{h}}$ and the decrease of $\mathrm{DC}_{-100 \mathrm{mT}}$ with soil age means the more and more antiferromagnetic minerals appeared in the soils due to the transformatiuon of ferrimagentic minerals to antiferromagentic minerals. From the values of $\operatorname{IRM}_{\mathrm{h}}$, it may be concluded that the magnetic minerals in $0.01 \mathrm{Ma}$ proflie is dominated by the little amount of ferrimagnetic minerals, but $0.58 \mathrm{Ma}$ and 1.33 Ma profiles contain ferrimagnetic minerals and antiferromagentic minerals, while in the $6.12 \mathrm{Ma}$ the magnetic minerals are dominated by antiferromagentic minerals.

\subsection{Evolution Mechanism of Magnetic Parameters}

Soil magnetism is dominated by magnetic minerals, particularly by ferrimagentic minerals. It has been proved well that the evolution mechanism of soil magnetism are mainly on the following two underlying hypotheses: with pedogenic development, firstly, the lithogenic ferromagnetic minerals, in subtropical and tropical basalts mainly magnetite and titanomagnetite, were weathered gradually and partly transformed into maghemite, hematite; secondly, at the same time nano-sized pedogenic grains (mainly SP grains) of ferromagnetic minerals were being progressively formed [9,14,25,32-34,].

$\mathrm{X}$-ray diffraction results of iron oxides from Huang et al. [9] (see Table 2) in the similar basalt-derived chronosequence soils in northern Hainan Island were cited here to show the transform of ferromagnetic minerals, from Table 2 it can be found with the increase in soil forming age magnetite descended while hematite and maghemite ascended in fine earth fraction and clay fraction. Although now it is impossible to differentiate between magnetite and maghemite using X-ray diffraction

Table 2. Iron oxides in soils at different developing and weathering age (cited from [9]).

\begin{tabular}{ccc}
\hline Age & Iron oxides in clay fraction $(<2 \mu \mathrm{m})$ & Iron oxides in fine earth $(<2 \mathrm{~mm})$ \\
\hline $0.01 \mathrm{Ma}$ & $\mathrm{He}(+)$ & $\mathrm{Tm}(+)$, magnetite $(+)$ \\
$0.58 \mathrm{Ma}$ & $\mathrm{He}(+), \mathrm{Tm}(+)$ & $\mathrm{He}(+++), \mathrm{Go}(+++)$ \\
$1.33 \mathrm{Ma}$ & $\mathrm{He}(+++), \mathrm{Go}(+++), \mathrm{Mh}(+)$ & $\mathrm{He}(+++), \mathrm{Mh}(++), \mathrm{Go}(++)$ \\
$6.12 \mathrm{Ma}$ & $\mathrm{He}(+++), \mathrm{Mh}(++)$ &
\end{tabular}

He, hematite; Mn, magnetite; Tm, Titanomagnetite; Go, gothite; Mh, maghemite; +, small amount; ++, certain amount; +++, larger amount. 
because their peaks are very close and practically indistinguishable, studies found that the corresponding magnetic phase in the superparamagnetic (SP) and single domain (SD) particles is maghemite rather than magnetite because pedogenic ferrimagnetic mineral particles with high surface to volume ratios are eventually oxidized into maghemite regardless of their initial states (magnetite or maghemite). To prove the maghemite is the main controbutor to the mangetism of studied soil profiles, DCB solution is used to treated the soil samples, it found that FDS after DCB solution treatment decreased by $58.0 \% \sim 95.7 \%$ with a mean of $81.6 \%$, which indicates the high content and the significant contribution of maghemite to soil magnetism in the studied soils because DCB solution can dissolve nanosized $(<100 \mathrm{~nm})$ magnetite but not maghemite [7,35-37].

The grain sizes of magentic minerals in soils are usually less than $2 \mu \mathrm{m}$ (clay fractions), LD techniques can provide the information of PSD distributions of clays $[38,39]$. Figure 3 showed that Primosls is domintaed by the particles of $0.4-2 \mu \mathrm{m}$ (PSD grains, $0.05-1 \mu \mathrm{m}$; MD grains, $1-2 \mu \mathrm{m}$ ), and then from Ferrosols to Ferralosols the particles of $\leq 0.4 \mu \mathrm{m}$ increased obvisouly, means more finer particles formed. Due to the detect limit (usually is 0.04 or $0.05 \mu \mathrm{m}$ ) of LD instrument, it can't give PSD informatoion of particle fractions of $\leq 0.04$ or 0.05 $\mu \mathrm{m}$, however, the uniform PSD distribution patterns in clay fractions in Ferrosols and Ferralosols may indicate that PSD similarity of magnetic iorn oxides in Ferrosols and Ferralosols.

\subsection{Potential Significance of Magnetic Parameters in Identifying Soil Types?}

The data of the less disturbed B horizons of the studied soils were used here to explore the potential significance of magnetic parameters in identifying soil types (Figure 4). Significant correlations existed between FDS, $\mathrm{ARM}, \mathrm{SIRM}, \mathrm{IRM}_{\mathrm{s}}$ and soil age, among of which, a positive exponential correlation for FDS, while negative

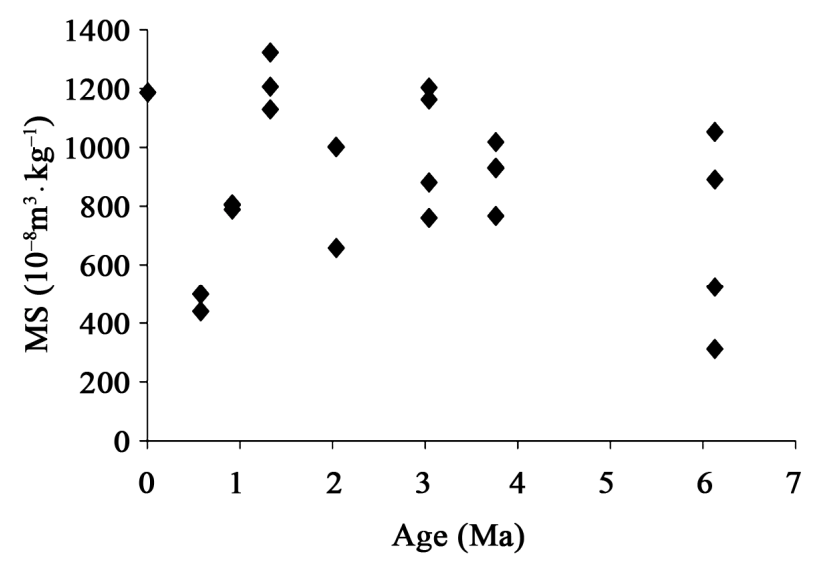

Copyright $\odot 2011$ SciRes. logarithmic correlations for ARM, SIRM and $\mathrm{IRM}_{\mathrm{s}}$, which proved that these magnetic parameters of B can indicate the soil age or soil development degree, which were already disclosed well by other studies (for examples, $[7,25])$.

It could be also found from Figure 4 that in the period of Ferrolosols (1.33 Ma ), FDS, ARM, SIRM and IRM changed slowly, suggesting a relative stable phase occurred at $1.33 \mathrm{Ma}$ for soil magnetic parameters, which may be regarded as a stable phase to be added into $\mathrm{Lu}$ et al.'s new conceptal model of soil magentism evolution [25], the lack of this new stable phase in Lu et al.'s model is attributed to no Ferrolosols in subtropical Zhejiang province.

The existence of the stable phase may be proved from one aspect by the temporal changes of clay content and $\mathrm{Fe}_{\mathrm{t}}$ and $\mathrm{Fe}_{\mathrm{d}}$. Soil magnetism is mainly dominated by the contents, components and grain sizes of magnetic iron oxides. Iron oxides are concentrated mainly in the fine fractions of soils in subtropical and tropical regions, particularly in clay fractions. Figure 5 shows Ferralosols was dominated by clay fractions and $\mathrm{Fe}_{\mathrm{t}}$ and $\mathrm{Fe}_{\mathrm{d}}$ changed little in Ferralosols stage.

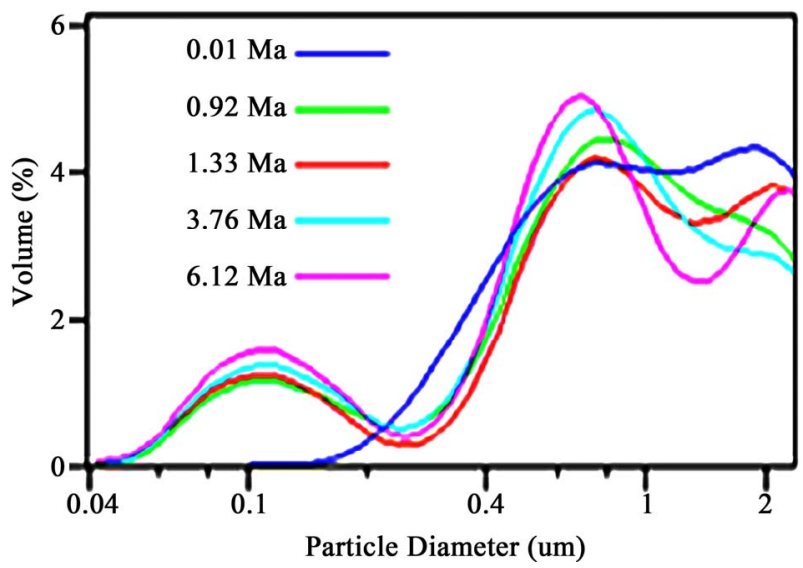

Figure 3. The temporal changes of clay fractions of basaltderived chronosequence soils.

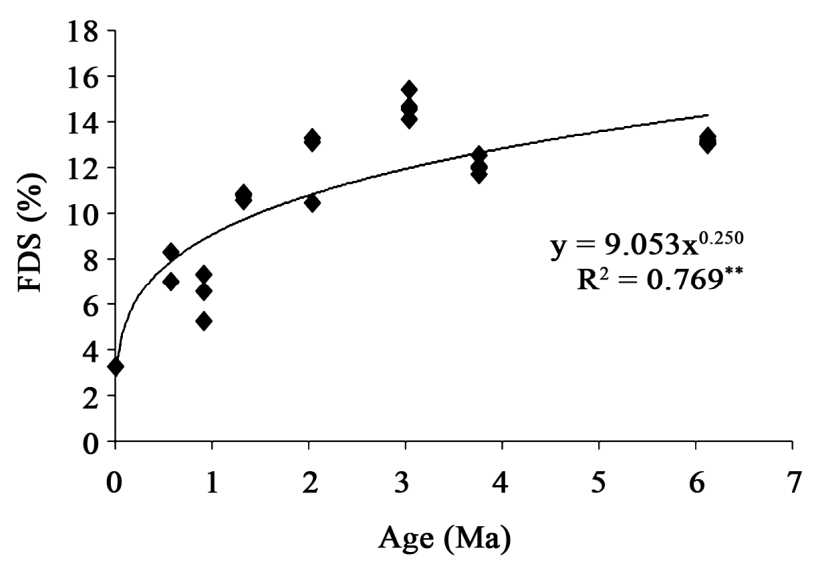

Openly accessible at http://www.scirp.org/journal/AS/ 

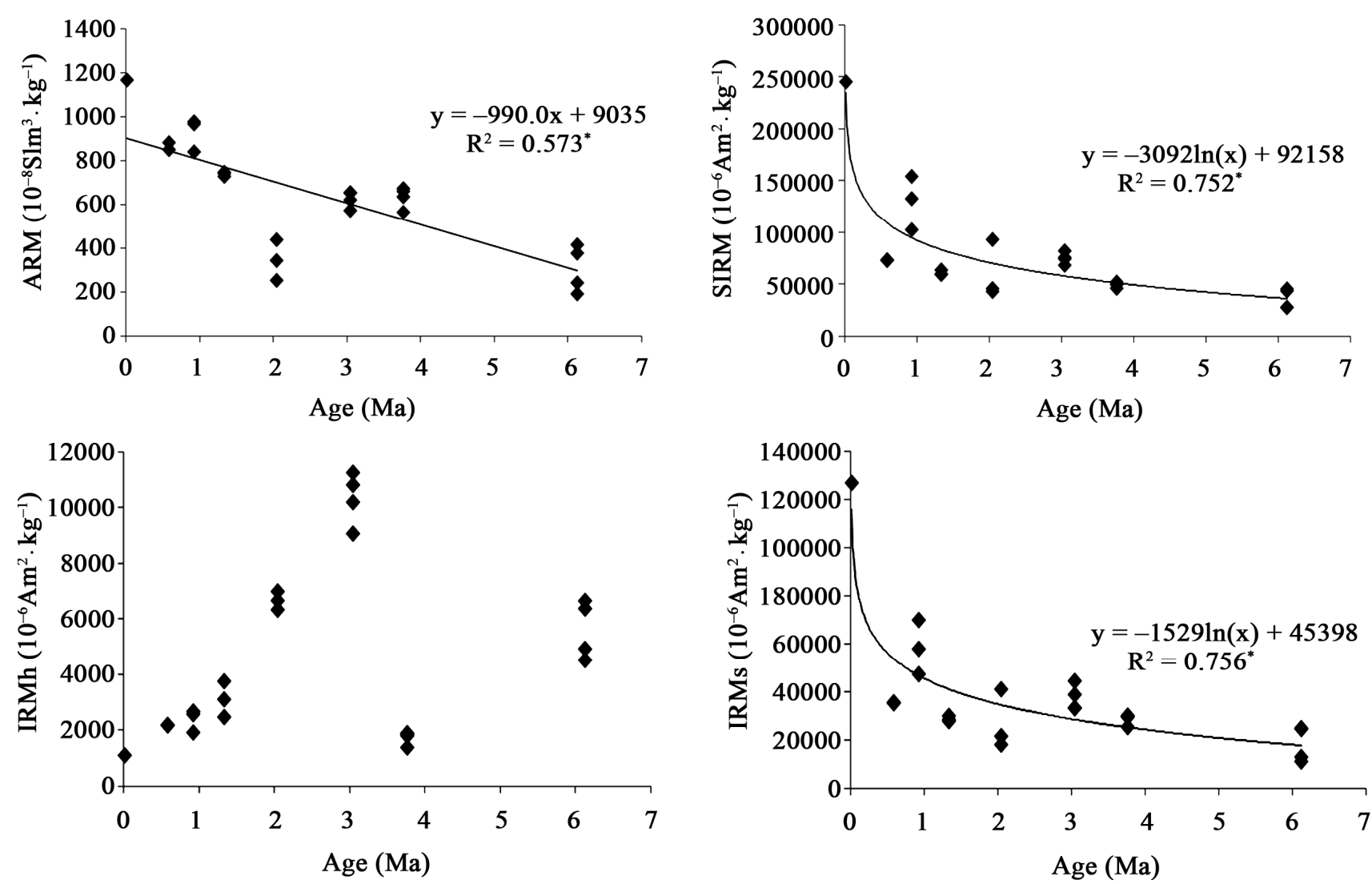

Figure 4. The temporal changes of magnetic parameters of $\mathrm{B}$ horizons of basalt-derived chronosequence soils. $\mathrm{R}^{2^{*}}$ significant at $\mathrm{P}<$ 0.05 level, $\mathrm{R}^{2 * *}$ significant at $\mathrm{P}<0.01$ level.
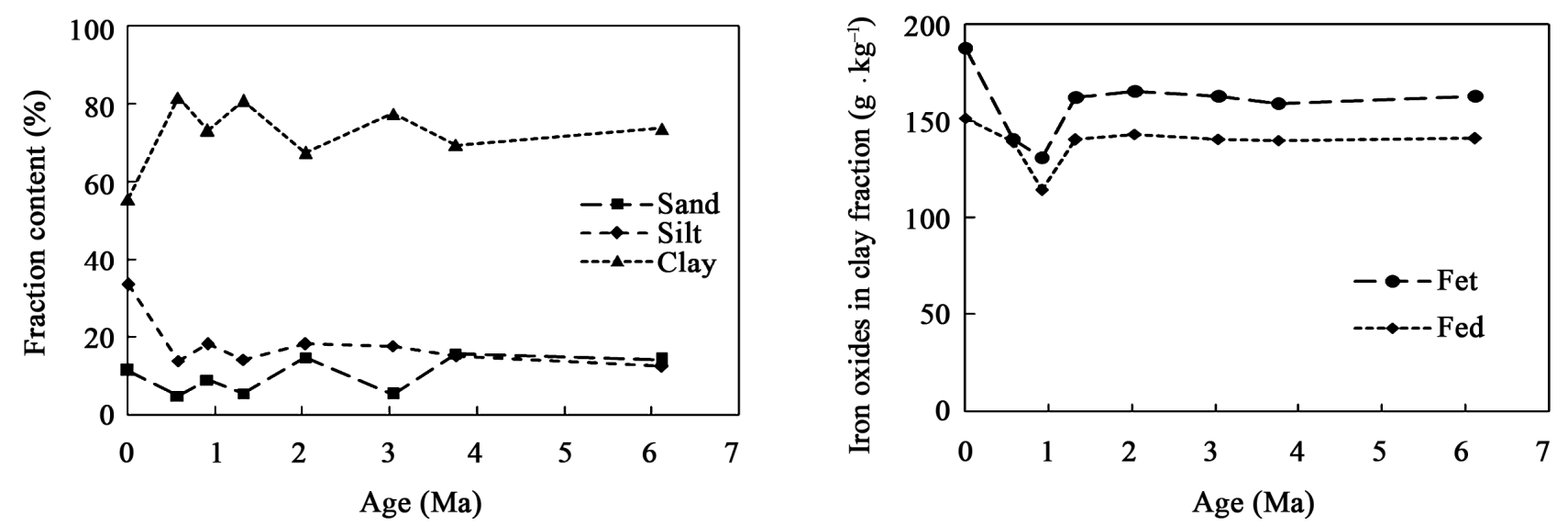

Figure 5. The temporal changes of clay content, $\mathrm{Fe}_{\mathrm{t}}$ and $\mathrm{Fe}_{\mathrm{d}}$ of $\mathrm{B}$ horizons of basalt-derived soils.

The above stable phase is significant in Ferraloslos identification with soil magnetism. From Figure 4 it can be found that obvious differences in the values of FD and ARM between Ferralosols and other soils, i.e., Primosols or Ferrosols: FDS, Ferralosols $>10 \%$, Primosols and Ferrosols $<10 \%$; ARM, Ferralosols $<7000 \times 10^{-8}$ $\mathrm{SIm}^{3} \cdot \mathrm{kg}^{-1}$, Primosols and Ferrosols $>8000 \times 10^{-8}$ $\mathrm{SIm}^{3} \cdot \mathrm{kg}^{-1}$.
With the consideration of the measured values of magnetic parameters in other studies on basalt-derived soils $[7,25,40]$, for examples, FDS of Ferralosols B horizons in Huang and Gong [7] were also $>10 \%$, while < $10 \%$ in other soil types; in the five soil profiles of Lu et al. [25], B horizons FDS\% of four profiles were $<10 \%$, therefore, it is possible to use magnetic indices to identify Ferralosols in tropical region. To establish the mag- 
netic diagnostic indices of soils, one way more reliable is by the systematical collection and analysis of enough soil samples, but it is costly in time and fund; the other way more conveniently may be by studying the chronosequence soils as we did here. However, we advise here that more studies need to validate the above-mentioned magnetic indices and they should be used simultaneously with the existing other indices of profile morphological, physical and chemical properties.

\section{CONCLUSIONS}

Our study disclosed further that evolution of soil magnetic parameters with soil age, and they changed fast from Primosols to Ferrosols but slowly during Ferralosols, which suggested a relative stable phase occurred in Ferrolosols phase, it proves the possibility to use establish magnetic diagnostic indices for Ferralosols identification in the tropical regions.

\section{ACKNOWLEDGEMENTS}

This study was jointly supported by the Knowledge Innovation Program of the Chinese Academy of Sciences (KZCX2-YW-409) and the National Natural Science Foundation of China (Nos. 40771091 and 40625001). We thank Dr. Yaoguo $\mathrm{Hu}$ of Guangdong Institute of Eco-Environment and Soil Sciences) and Prof. Zhiping Qi of Hainan University for their helps in soil sampling.

\section{REFERENCES}

[1] Stevens, P.R. and Walker, T.W. (1970) The chronosequence concept and soil formation. The Quarterly Review of Biology, 45, 333-350. doi:10.1086/406646

[2] Kennedy, M.J., Chadwick, O.A., Vitousek, P.M., Derry, L.A. and Hendricks, D.M. (1998) Changing sources of base cations during ecosystem development, Hawaiian Islands. Geology, 26, 1015-1018. doi:10.1130/0091-7613(1998)026<1015:CSOBCD $>2.3$. $\mathrm{CO} ; 2$

[3] Chadwick, O.A., Derry, L.A., Vitousek, P.M., Huebert, B.M. and Hedin, L.O. (1999) Changing sources of nutrients during four million years of ecosystem development. Nature, 397, 491-497. doi:10.1038/17276

[4] Chadwick, O.A., Gavenda, R.T., Kelly, E.F., Ziegler, K., Olson, C.G., Elliott, W.C. and Hendricks, D.M. (2003) The impact of climate on the biogeochemical functioning of volcanic soils. Chemical Geology, 202, 195-223. doi:10.1016/j.chemgeo.2002.09.001

[5] Kurtz, A.C., Derry, L.A., Chadwick, O.A. and Alfano, M.J. (2000) Refractory element mobility in volcanic soils. Geology, 28, 683-686. doi:10.1130/0091-7613(2000)28<683:REMIVS >2.0.CO; $\underline{2}$

[6] Derry, L.A., Kurtz, A.C., Ziegler, K. and Chadwick, O.A. (2005) Biological control of terrestrial silica cycling and export fluxes to watersheds. Nature, 433, 728-731. doi:10.1038/nature03299
[7] Huang, C.M. and Gong, Z.T. (2000) Magnetic characteristics during process of tropical soil development. $M a-$ rine Geology \& Quaternary Geology, 20, 63-68.

[8] Huang, C.M., Gong Z.T. and Yang, D.Y. (2001) Comparison of clay minerals in soils derived from basalt materials in northern Hainan island. Southwest China Journal of Agricultural Sciences, 14.

[9] Huang, C.M., Gong, Z.T. and Yang, D.Y. (2002) Genesis of soils derived from basalt in northern Hainan Island. II. Iron oxides. Acta Pedologica Sinica, 39, 449-457.

[10] Zhang, G.L., Pan, J.H., Huang, C.M. and Gong, Z.T. (2007) Geochemical features of a soil chronosequence developed on basalt in Hainan Island, China. Revista Mexicana de Ciencias Geológicas, 24, 261-269.

[11] Maher, B.A. (1986) Characterization of soils by mineral magnetic measurements. Physics of the Earth and Planetary Interiors, 42, 76-92. doi:10.1016/S0031-9201(86)80010-3

[12] Resende, M., Santana, D.P., Franzmeier, D.P. and Coey, J.M.D. (1986) Magnetic properties of Brazilian Oxisols. Proceedings of the International Soil Classification Workshop, EMBRAPA, Rio de Janeiro, 20 June-1 July 1986, 78-108.

[13] Resende, M., Santana, D.P. and Rezende, S.B. (1988) Susceptibilidade magnetica em Latossolos do Sudeste e Sul do Brasil. In: Camargo, M.C., Ed., Proceedings of III Soil Correlation and Classification Meeting, EMBRAPA, Rio de Janeiro, 233-258.

[14] Fontes, M.P.F., De Oliveira, T.S., Da Costa, L.M. and Campos, A.A.G. (2000) Magnetic separation and valuation of magnetization of Brazilian soils from different parent materials. Geoderma, 96, 81-99. doi:10.1016/S0016-7061(00)00005-7

[15] Cooperative Research Group on Chinese Soil Taxonomy (CRGCST) (2001) Chinese soil taxonomy. Science Press, Beijing, 246-247.

[16] Huang, Z.G., Zhang, W.Q. and Chen, H.J. (1999) Red soils in China and the shift of its border. Journal of Geographical Science, 54, 193-205.

[17] Ge, T.M., Chen, W.J., Xu, X., Lee, D.M., Fan, L.M., Lee, Q., Wen, S.Y. and Wang, X. (1989) The geomagnetic polarity time scale of Quaternary for Leiqiong area. K-Ar dating and palaeomagnetic evidence from volcanic rocks. Acta Geophysica Sinica, 32, 550-557.

[18] Zhu, B.Q. and Wang, H.F. (1989) Nd-Sr-Pb isotopic and chemical evidence for the volcanism with MORB-OIB source characteristics in the Leiqiong area, China. Geochimica, 3, 193-201.

[19] Ho, K.S., Chen, J.C. and Juang, W.S. (2000) Geochronology and geochemistry of late Cenozoic basalts from the Leiqiong area, southern China. Journal of Asian Earth Sciences, 18, 307-324. doi:10.1016/S1367-9120(99)00059-0

[20] Rabenhorst, M.C. (1997) The chrono-continuum: An approach to modeling pedogenesis in marsh soils along transgressive coastlines. Soil Science, 162, 2-9. doi:10.1097/00010694-199701000-00002

[21] Torrent, J., Schwertmann, U. and Schulze, D.G. (1980) Iron oxide mineralogy of some soils of two river terrace sequences in Spain. Geoderma, 23, 191-208. doi:10.1016/0016-7061(80)90002-6

[22] Schwertmann, U. (1985) The effect of pedogenic envi- 
ronments on iron oxide minerals. Advances in Soil Science, 1, 171-200. doi:10.1007/978-1-4612-5046-3 5

[23] Pai, C.W., Wang, M.K., Zhuang, S.Y. and King, H.B. (2004) Free and noncrystalline Fe-oxides to total iron concentration ratios correlated with ${ }^{14} \mathrm{C}$ ages of three forest soils in central Taiwan. Soil Science, 169, 582-589. doi:10.1097/01.ss.0000138419.22546.00

[24] Tsai, H., Huang, W.S., Hseu, Z.Y. and Chen, Z.S. (2006) A river terrace soil chronosequence of the Pakua Tableland in central Taiwan. Soil Science, 171, 167-179. doi:10.1097/01.ss.0000187376.76767.21

[25] Lu, S.G., Xue, Q.F., Zhu, L. and Yu, J.Y. (2008) Mineral magnetic properties of a weathering sequence of soils derived from basalt in Eastern China. Catena, 73, 23-33. doi:10.1016/j.catena.2007.08.004

[26] Chinese Society of Soil Science (CSSS). (1984) Standard methods of soil and agriochemistry. Science Press, Beijing.

[27] Mehra, O.P. and Jackson, M.L. (1960) Iron oxide removal from soils and clay by a dithionite-citrate system buffered with sodium bicarbonate. Clay and Clay Mineral, 7, 317-327. doi:10.1346/CCMN.1958.0070122

[28] Maher, B.A. (1988) Formation of ultrafine-grained magnetite in soil. Nature, 336, 368-370. doi: $10.1038 / 336368 \mathrm{a} 0$

[29] Dearing, J. (1999) Environmental magnetic susceptibility: Using the bartington MS2 system. Chi Publishing, Keniloworth.

[30] Fine, P., Singer, M.J. and Verosub, K.L. (1992) Use of magnetic susceptibility measurements in assessing soil uniformity in chronosequences studies. Soil Science Society of America Journal, 56, 1195-1199. doi:10.2136/sssaj1992.03615995005600040032x

[31] Singer, M.J., Fine, P., Verosub, K.L. and Chadwick, O.A. (1992) Time dependence of magnetic susceptibility of soil chronosequences on the California coast. Quaternary Research, 37, 332-336. doi:10.1016/0033-5894(92)90070-Y

[32] Torrent, J., Barrón, V. and Liu, Q.S. (2006) Magnetic enhancement is linked to and precedes hematite formation in aerobic soil. Geophysical Research Letter, 33, L02401. doi:10.1029/2005GL024818

[33] Torrent, J., Liu, Q.S., Bloemendal, J. and Barrón, V. (2007) Magnetic enhancement and iron oxides in the Upper Luochuan loess-paleosol sequence, Chinese Loess Plateau. Soil Science Society of America Journal, 71, 1570-1578. doi:10.2136/sssaj2006.0328

[34] Torrent, J., Liu, Q.S. and Barrón, V. (2009) Magnetic minerals in Calcic Luvisols (Chromic) developed in a warm Mediterranean region of Spain: Origin and paleoenvironmental significance. Geoderma.

[35] Fine, P. and Singer, M.J. (1989) Contribution of ferrimagnetic minerals to oxalate-and dithionite-extractable iron. Soil Science Society of America Journal, 53, 191-196. doi:10.2136/sssaj1989.03615995005300010035x

[36] Singer, M.J., Bowen, L.H., Verosub, K.L., Fine, P. and TenPas, J. (1995) Mössbauer spectroscopic evidence for citrate-bicarbonate-dithionite extraction of maghemite from soils. Clays and Clay Minerals, 43, 1-7. doi:10.1346/CCMN.1995.0430101

[37] Reyes, I. and Torrent, J. (1997) Citrate-ascorbate as a highly selective extractant for poorly crystalline iron oxides. Soil Science Society of America Journal, 61, 1647 1654. doi:10.2136/sssaj1997.03615995006100060015x

[38] Martin, M.A. and Montero, E. (2002) Laser diffraction and multifractal analysis for the characterization of dry soil volume-size distributions. Soil \& Tillage Research, 64, 113-123. doi:10.1016/S0167-1987(01)00249-5

[39] Linda, P., Marco, B. and Paola, R.P. (2006) Laser diffraction, transmission electron microscopy and image analysis to evaluate a bimodal Gaussian model for particle size distribution in soils. Geoderma, 135, 118-132. doi:10.1016/j.geoderma.2005.11.009

[40] Lu, S.G. (2000b) Magnetic properties of subtropical Ferrisols and its magnetic mineralogical study. Chinese Journal of Geophysics, 43, 498-504. 